\title{
Immunohistochemical and histomorphological analysis of rat mammary tumors after simvastatin treatment
}

\author{
P. KUBATKA ${ }^{1,2, *}$, K. KAJO ${ }^{3}$, K. ZIHLAVNIKOVA ${ }^{1}$, K. ADAMICOVA ${ }^{4}$, D. VYBOHOVA ${ }^{5}$, M. PEC $^{1,2}$, V. NOSAL $^{6}$, N. STOLLAROVA $^{2}$, B. BOJKOVA ${ }^{7}$ \\ M. KASSAYOVA 7 , P. ORENDAS ${ }^{7}$
}

${ }^{1}$ Department of Medical Biology, Jessenius Faculty of Medicine, Comenius University, Mala Hora 4, SK-036 01 Martin, Slovakia; ${ }^{2}$ Department of Biology and Ecology, Faculty of Education, Catholic University in Ruzomberok, Hrabovska cesta 2, SK-034 01 Ruzomberok, Slovakia; ${ }^{3}$ Department of Pathology, Slovak Medical University and St. Elisabeth Oncology Institute, Heydukova 10, SK-81108 Bratislava, and BB Biocyt, Diagnostic Centre, Ltd., Nam. L. Svobodu 1, SK-974 01 Banska Bystrica, Slovakia; ${ }^{4}$ Department of Pathological Anatomy, Jessenius Faculty of Medicine, Comenius University, Kollarova 2, 03659 Martin; ${ }^{5}$ Department of Anatomy, Jessenius Faculty of Medicine, Comenius University, Mala Hora 4, SK-036 01 Martin, Slovakia; ${ }^{6}$ Clinic of Neurology, Jessenius Faculty of Medicine, Comenius University (in University Hospital in Martin) Kollarova 2, SK-036 59 Martin, Slovakia; ${ }^{7}$ Institute of Biological and Ecological Sciences, Faculty of Science, P. J. Safarik University, Moyzesova 11, SK-041 67 Kosice, Slovakia

${ }^{*}$ Correspondence: kubatka@jfmed.uniba.sk

Received January 10, 2012 / Accepted March 23, 2012

\begin{abstract}
The results of experimental studies have indicated the pleiotropic effects of statins in organism, e.g. the influence on cell cycle, apoptosis or angiogenesis. In this study, the effects of simvastatin on selected parameters of apoptosis and proliferation in chemocarcinogen-induced mammary tumorigenesis in female rats were determined. Simvastatin was administered dietary at a dose of $18 \mathrm{mg} / \mathrm{kg}$ and highly effective dose of $180 \mathrm{mg} / \mathrm{kg}$ the entire experiment (18 weeks). At autopsy mammary tumors were removed and prepared for immunohistochemical and histomorphological analysis. In treated animals (simvastatin $180 \mathrm{mg} / \mathrm{kg}$ ), significant decrease by $12 \%$ in $\mathrm{Bcl}-2$ protein expression and non-significant decrease by $27 \%$ of Ki67 protein expression in tumor cells compared to tumor cells in control animals were observed after semiquantitative evaluation. Morphometrical analysis has shown significant proapototic shift in Bcl-2/Bax ratio in tumor cells. In high grade control carcinoma cells, the expression of Ki67 increased by $37 \%$ (non-significantly) in comparison with control low grade carcinomas. A histomorphological analysis of malignant tumors has revealed a shift from high grade to low grade carcinomas after simvastatin treatment. The noticeable decrease of mammary tumor frequency and incidence in rats after simvastatin treatment was accompanied with antiapoptotic Blc-2 protein decrease and proapoptotic Bax protein increase in this experiment.
\end{abstract}

Key words: rat, mammary tumors, simvastatin, Bcl-2, Bax, Ki67

Statins are 3-hydroxy-3-methylglutaryl CoA reductase (HMG-CoA) inhibitors with important role as hypolipidemic agents [1]. Within the last ten years, the results of experimental studies have indicated the pleiotropic effects of statins in organism which are mediated by their direct or indirect influence on cell cycle, apoptosis or angiogenesis. These physiological processes play a key role in neoplastic transformation, for this reason statins are seriously discussed by clinical and experimental oncologists.

Statins reduce not only serum cholesterol levels but also mevalonate synthesis. Mevalonate is a precursor of several major products regulating the cell cycle, including dolichol, geranylpyrophosphate (GPP) and farnesylpyrophosphate (FPP) [2]. Another product - geranylgeranylpyrophosphate (GGPP) can be synthesised from FPP. Both FPP and GGPP are substrates essential for the activation of variety protooncogenes, e.g. the inhibition of mevalonate pathway by statins can consequently block the Ras or Rho activation [3]. Statins have been shown to stabilize the cell cycle kinase inhibitors p21 and p27, and to arrest breast cancer cell lines in the G1 phase of the cell cycle [2].

Proposed mechanisms for statin-mediated apoptosis include an upregulation of pro-apoptotic protein expression (e.g., Bax, Bim), combined with decreased anti-apoptotic protein expression (e.g., Bcl-2) [4], or activation of caspase-3, caspase- 
8, and caspase-9 [5]. In the study of Agarwal et al. [6] it has been shown that addition of geranylgeranylated pyrophosphate prevented lovastatin induced apoptosis in colon cancer cells, whereas cotreatment with farnesyl pyrophosphate had no effect. This study also showed that lovastatin treatment resulted in decreased expression of the antiapoptotic protein $\mathrm{Bcl}-2$ and increased expression of proapoptotic protein Bax in cancer cells. In esophageal adenocarcinoma cells, statin treatment increased mRNA and protein expression of proapoptotic proteins Bax and Bad, but protein levels of antiapoptotic proteins $\mathrm{Bcl}-2$ and $\mathrm{Bcl}-\mathrm{X}-\mathrm{L}$ were unchanged [7]. In another study, the anticarcinogenic potential of fluvastatin was evaluated in three hepatocellular carcinoma cell lines (HepG2, SMMC-7721 and MHCC-97H). After fluvastatin treatment, expression of $\mathrm{Bcl}-2$ and procaspase- 9 were downregulated, cytochrome c (cytosolic extract), Bax and cleaved-caspase-3 protein expression increased [8]. In this context, pro-apoptotic shift of ratio in Bax/Bcl-2 mRNA expression in rat mammary tumor cells caused by atorvastatin in our previous experiment was confirmed [9].

The above mentioned observations have led us to hypothesize that statins might inhibit also proliferation and induce apoptosis in rat mammary tumor cells in our preventivecurative model. Ki67 is an excellent marker to determine the growth fraction of a given cell population [10]. The fraction of Ki67 - positive tumor cells (the Ki67 labeling index) is often correlated with the clinical course of cancer. In this study, the immunohistochemical analysis of Ki67 and Bcl-2 and Bax proteins as the apoptotic parameters after simvastatin treatment will be determined. Another aim of this study - a histomorphological analysis of mammary tumors - may have implications for assessment of simvastatin on the differentiation and prognosis of the tumors after long-term treatment and or the efficacy of drug.

\section{Materials and methods}

Female rats of Sprague-Dawley strain obtained from AnLab (Prague, Czech Republic) aged 31-35 days were used in the experiment. The animals were adapted to standard vivarium conditions with temperature $23 \pm 2{ }^{\circ} \mathrm{C}$, relative humidity 40 $60 \%$, artificial regimen light : dark $(12 \mathrm{~h}: 12 \mathrm{~h}$ ) (lights on from 6 a.m., light intensity 150 lux per cage). During the experiment the animals were fed by the Ssniff diet (Soest, Germany) and drank tap water ad libitum. Mammary carcinogenesis was induced by N-methyl-N-nitrosourea (NMU) (Sigma, Deisenhofen, Germany) administered intraperitoneally in one dose of $50 \mathrm{mg} / \mathrm{kg}$ body weight on average the $41^{\text {th }}$ postnatal day. Car- cinogen was freshly prepared and dissolved in isotonic saline solution. Simvastatin synthesized by Zentiva (Prague, Czech Republic) was administered in the diet at two concentrations: $18 \mathrm{mg} / \mathrm{kg}(0.0018 \%)$ and $180 \mathrm{mg} / \mathrm{kg}(0.018 \%)$. The lower average dose of simvastatin in this experiment was equivalent to the maximal daily clinical dose of Zocor administered to patients with hypercholesterolemia. Based on our previous experience with statins ' use in rat mammary carcinogenesis (statins in rats demonstrate different pharmacokinetics and pharmacodynamics than in humans), it was necessary to use high doses of simvastatin $(180 \mathrm{mg} / \mathrm{kg})$ to prove its antineoplastic effect in this experiment. Chemoprevention with simvastatin began 1 week before carcinogen administration and lasted until the end of the experiment - 17 weeks after NMU administration. Animals were randomly assigned to one of three experimental groups: 1 . control group without chemoprevention; 2 . chemoprevention with simvastatin at a concentration of $18 \mathrm{mg} / \mathrm{kg}$ in the chow (SIMVA 18); 3. chemoprevention with simvastatin at a concentration of $180 \mathrm{mg} / \mathrm{kg}$ in the chow (SIMVA 180). Each group consisted of 20 animals. The animals were weekly weighted and since $6^{\text {th }}$ week post NMU palpated in order to register the presence, number, location and size of each palpable tumor.

In the last $-18^{\text {th }}$ week of the experiment, the animals were quickly decapitated, mammary tumors were excised and tumor size was recorded. Macroscopic changes in selected organs (liver, kidney, stomach, intestine and lung) were evaluated at autopsy. The parameters of mammary carcinogenesis (tumor incidence, frequency, latency and volume) were evaluated in each experimental group. Tissue samples of each mammary tumor were routinely formalin-fixed and paraffin-embedded. The tumors were classified according to the criteria for the classification of rat mammary tumors [11]. The additional parameter - grade of invasive carcinomas was used. Tumor samples were divided into low-grade (LG) and high-grade (HG) carcinomas. The criteria for categorization - solidization, cell atypia, mitotic activity index, and necrosis, were chosen according to the standard diagnostic method of classification. As HG carcinomas were considered tumors with $\geq 2$ positive criteria, LG carcinomas were tumors with $\leq 1$ positive criterium. The solidization was considered if $>30 \%$ of tumor sample displays solid growth, high mitotic activity index if $\geq 10$ mitosis was observed in 10 high power fields and necrosis if the occurrence of comedo (not infarct) was determined.

The paraffin block having the most representative tumor area of each mammary tumor was chosen for immunohistochemical analysis of Ki67, Bcl-2 and Bax protein expression. A Table 1 summarizes the clone, source concentration, and

Table 1. Summary of used antibodies

\begin{tabular}{lllcc}
\hline Antibody against to & \multicolumn{1}{c}{ Clone } & \multicolumn{1}{c}{ Source } & Concentration & Time of incubation \\
\hline Ki67 & mouse monoclonal, MIB-5, M7248 & DAKO, Glostrup, DK & $1: 50$ & $30 \mathrm{~min}$ \\
Bcl-2 & rabbit polyclonal, N-19, SC492 & Santa Cruz Biotechnology, CA, USA & $1: 450$ & $30 \mathrm{~min}$ \\
Bax & rabbit polyclonal, P-19, SC526 & Santa Cruz Biotechnology, CA, USA & $1: 450$ & $30 \mathrm{~min}$ \\
\hline
\end{tabular}


Table 2. Histopathological classification of mammary tumors and grade of malignat lessions.

\begin{tabular}{|c|c|c|c|c|c|c|}
\hline $\begin{array}{c}\text { Animal } \\
\text { (number) }\end{array}$ & Type & Grade & SOLID & ATYP & MAI & NECR \\
\hline \multicolumn{7}{|c|}{ CONTROL GROUP, 36 lesions, 12 tumor bearing animals } \\
\hline 3 & $\mathrm{C}$ & HG & - & + & + & $+/-$ \\
\hline 3 & TA & & & & & \\
\hline 4 & $\mathrm{P}-\mathrm{C}$ & HG & + & - & - & + \\
\hline 4 & $\mathrm{P}$ & LG & - & - & - & - \\
\hline 4 & $\mathrm{C}$ & LG & - & - & - & - \\
\hline 5 & $\mathrm{P}-\mathrm{C}$ & HG & + & + & + & - \\
\hline 5 & P-C & LG & - & - & - & - \\
\hline 7 & PAP & & & & & \\
\hline 8 & $\mathrm{P}$ & LG & - & - & - & - \\
\hline 8 & $\mathrm{C}$ & LG & - & - & - & - \\
\hline 8 & $\mathrm{P}$ & LG & - & - & - & - \\
\hline 8 & P-C & HG & $-1+$ & + & + & - \\
\hline 9 & P-C & HG & $-1+$ & + & + & - \\
\hline 10 & C-P-CO & HG & - & + & - & + \\
\hline 11 & C-P & LG & - & - & - & - \\
\hline 14 & $\mathrm{C}$ & HG & + & + & + & - \\
\hline 14 & C & LG & - & - & - & - \\
\hline 14 & $\mathrm{C}$ & LG & - & - & - & - \\
\hline 14 & C-P & LG & - & - & - & - \\
\hline 14 & P-C & HG & - & + & + & - \\
\hline 16 & C-P & LG & - & - & - & - \\
\hline 16 & $\mathrm{C}-\mathrm{CO}$ & LG & - & - & - & + \\
\hline 16 & C-P & LG & - & - & - & - \\
\hline 16 & $\mathrm{C}-\mathrm{CO}$ & HG & + & + & + & + \\
\hline 16 & C-P & $\mathrm{LG}$ & - & - & - & - \\
\hline 16 & C-P & LG & - & - & - & - \\
\hline 16 & PAP & & & & & \\
\hline 16 & C-P & HG & + & + & + & + \\
\hline 16 & C-P & HG & - & + & - & + \\
\hline 18 & P-C & LG & - & - & - & - \\
\hline 20 & C-P & HG & - & + & + & $-1+$ \\
\hline 20 & C-P & HG & + & + & - & + \\
\hline 20 & C-P-CO & HG & + & + & + & + \\
\hline 20 & P-C & HG & + & + & + & - \\
\hline 20 & $\mathrm{C}-\mathrm{CO}$ & HG & + & + & + & + \\
\hline 20 & C-P & LG & - & - & - & - \\
\hline \multicolumn{7}{|c|}{ SIMVA 18 GROUP, 35 lesions, 15 tumor bearing animals } \\
\hline 22 & C-P & LG & - & - & - & - \\
\hline 22 & $\mathrm{C}-\mathrm{P}$ & HG & + & + & - & - \\
\hline 22 & $\mathrm{C}-\mathrm{P}$ & LG & - & - & - & - \\
\hline 23 & PAP & & & & & \\
\hline 24 & $\mathrm{P}-\mathrm{C}$ & LG & + & - & - & - \\
\hline 24 & C-P & LG & - & - & - & + \\
\hline 24 & $\mathrm{P}-\mathrm{C}-\mathrm{CO}$ & HG & + & + & + & + \\
\hline
\end{tabular}

\begin{tabular}{|c|c|c|c|c|c|c|}
\hline $\begin{array}{c}\text { Animal } \\
\text { (number) }\end{array}$ & Type & Grade & SOLID & ATYP & MAI & NECR \\
\hline 24 & C-P & HG & + & + & + & + \\
\hline 25 & C-P & LG & + & - & - & - \\
\hline 25 & PAP & & & & & \\
\hline 27 & C-P & HG & + & + & - & - \\
\hline 27 & C-P & LG & - & - & - & - \\
\hline 27 & C-P & HG & + & + & + & + \\
\hline 28 & C-P & LG & - & - & - & - \\
\hline 28 & C-P & HG & + & + & + & + \\
\hline 28 & C-P & LG & - & - & - & - \\
\hline 29 & P-C & HG & - & + & + & - \\
\hline 30 & P-C & LG & - & - & - & - \\
\hline 30 & C-P & LG & - & - & - & - \\
\hline 30 & C-P & LG & - & - & - & - \\
\hline 31 & $\mathrm{C}$ & LG & - & - & - & - \\
\hline 31 & $\mathrm{C}$ & HG & + & + & + & + \\
\hline 31 & P-C & LG & - & - & - & - \\
\hline 33 & $\mathrm{C}-\mathrm{CO}$ & HG & + & + & + & + \\
\hline 34 & C-P-CO & HG & + & + & + & + \\
\hline 36 & $\mathrm{P}$ & LG & - & - & - & - \\
\hline 36 & $\mathrm{C}$ & LG & - & - & - & - \\
\hline 37 & $\mathrm{C}$ & LG & - & - & - & - \\
\hline 37 & DCIS & & & & & \\
\hline 38 & $\mathrm{P}$ & LG & - & - & - & - \\
\hline 38 & $\mathrm{P}$ & LG & - & - & - & - \\
\hline 38 & $\mathrm{C}-\mathrm{CO}$ & HG & - & + & + & + \\
\hline 39 & $\mathrm{C}$ & LG & - & + & - & - \\
\hline 39 & PAP-LN & & & & & \\
\hline 39 & C-P & LG & - & + & - & - \\
\hline \multicolumn{7}{|c|}{ SIMVA 180 GROUP - 7 lesions, 5 tumor bearing animals } \\
\hline 50 & PAP & & & & & \\
\hline 51 & $\mathrm{C}$ & HG & + & + & + & + \\
\hline 51 & PAP & & & & & \\
\hline 55 & $\mathrm{C}$ & LG & - & - & - & - \\
\hline 57 & PAP & & & & & \\
\hline 57 & P-C & LG & - & - & - & - \\
\hline 58 & PAP & & & & & \\
\hline
\end{tabular}

Type: invasive carcinoma (C- cribriform, $\mathrm{P}$ - papillary, CO - comedo), DCIS - ductal carcinoma in situ,

PAP - papilloma, TA - tubular adenoma, LN - lymph node. Dominant type in mixed tumors is the first in order.

Staging was evaluated only in invasive carcinomas, LG (low-grade) - well differentiated carcinomas,

HG (high-grade) - poorly differentiated carcinomas; SOLID - solidization; ATYP - cell atypia;

MAI - mitotic activity index, NECR - necrosis.

Explanatory note: SOLID - if $>30 \%$ of tumor sample displays solid growth; MAI - if $\geq 10$ mitosis is observed in 10 high power fields; NECR - occurrence of comedo (not infarct) necrosis.

HG - tumor with $\geq 2$ positive criteria, LG - tumor with $\leq 1$ positive criteria. 
time of incubation of antibodies used in experiment. Immunohistochemical staining was evaluated by a semiquantitative method based on percentage representation of positively responded elements. Positivity of staining was assessed as percentage of positive cells. The only criterion of positivity in semiquantitative method was the difference against negative stromal component. In the $\mathrm{Bcl}-2 / \mathrm{Bax}$ ratio evaluation, a morphometrical analysis as a method for precise analysis of protein expression in tumor cells was used. In morphometry, the expression of markers (positivity) was evaluated from the set limit. Moreover in this method not only carcinoma cells were evaluated but also stromal elements ("all the cells of tumor tissue"). Possible differences in results between semiquantitative and morphometrical analysis arise from different threshold positivity setting and from different spectrum of evaluated elements. Morphometric analysis of the digital images was done by software QuickPhoto Micro version 2.3 (Promicra, Prague, Czech Republic). Phase analysis function was used for the quantitative determination of Bcl-2 and Bax immunohistochemically positive cells. The area of labeled cells was percentually evaluated with standard thresholds for weak, mild and strong intensity /for three degrees of intensity/ of immunoreactivity in standard fields. Protein expression of Bcl-2 and Bax was analysed in the cytoplasm of tumor cells separately. During interphase, Ki67 can be exclusively detected within the nucleus, whereas in mitosis most of the protein is relocated to the surface of the chromosomes. The Ki67 protein is present during all active phases of the cell cycle, but is absent in resting cells, therefore it is an excellent marker for determining the growth fraction of cell population. Photographs were taken by an Olympus BX41, digital camera model No. SP 350. MannWhitney -U test, Kruskal-Wallis and one-way analysis of variance were statistical methods used in data evaluation in this experiment.

\section{Results}

This experiment is a continuation to our previous study where the significant tumor-suppressive effects of simvastatin (SIMVA 180) in the chemoprevention of rat mammary carcinogenesis were observed [12]. Simvastatin administered at a lower dose (SIMVA 18) did not change parameters of mammary carcinogenesis; therefore immunohistochemical analysis was realized only in rat mammary tumor cells from the control and the SIMVA 180 group.

A histopathological classification of mammary tumors has revealed a shift in the rate of poorly differentiated (high grade, HG) and well differentiated (low grade, LG) invasive tumors to higher representation LG invasive tumors after treatment with simvastatin [control group: 16/17 (HG/LG); SIMVA 18: 11/20; SIMVA 180: 1/2]. The treatment with simvastatin in higher dose apparently changed the rate from malignant to benign lesions (control group - 33/3, SIMVA 180 - 3/4) (Table 2).

The expression of Ki67, Bcl-2 and Bax proteins as percentage of positive cells in treated and control tumor cells and in control low grade and high grade invasive tumors were evaluated by semiquantitative method (Table 3 ). The decrease by $27 \%$ (12.93 \pm 3.01 vs $17.70 \pm 1.80)$ of Ki67 protein expression in treated tumor cells compared to tumor cells in control animals was observed. The median Ki67 percentage positivity in the control tumor cells was 20.0 (range $1-40$ ) and in the treated tumor cells was $15.0(0.5-20)$. Using non-parametric MannWhitney test, the difference was non-significant $(\mathrm{P}=0.273)$. Figure 1a shows immunohistochemical detection of Ki67 in control and treated tumor cells. Only slight correlation was found between Ki67 and Bcl-2 expression decrease in tumor cells in treated rats $(\mathrm{r}=0.454 ; \mathrm{P}=0.084)$. In high grade control tumor cells, the expression of Ki67 protein increased by $37 \%$ $(\mathrm{P}=0.127)$ in comparison with low grade control group (Figure 2, Table 3).

In treated animals (SIMVA 180), significant decrease by $12 \%(82.82 \pm 6.06$ vs $94.41 \pm 1.47)(\mathrm{P}=0.015)$ in $\mathrm{Bcl}-2$ protein expression in tumor cells compared to tumor cells in control animals was observed. The median Bcl-2 percentage positivity in tumor cells in treated animals was $90.0(50-100)$ and in control animals was $100.0(70-100)$. Compared to control cells, Bax protein expression was decreased in treated tumor cells by $13 \%(67.14 \pm 11.69$ vs $77.06 \pm 3.57)$ but the difference was not significant compared to control tumors $(\mathrm{P}=0.584)$. The median Bax percentage positivity in treated tumor cells was $70.0(30-100)$ respectively $80.0(20-100)$ in control tumor cells. Compared to semiquantitative method, the morphometrical analysis has shown more evident proapoptotic shift in the evaluation of $\mathrm{Bcl}-2 / \mathrm{Bax}$ protein expression (Table 4). Figure 1 b,c shows immunohistochemical detection of Bcl-2 and Bax proteins in control and treated tumor cells. Protein

Table 3. Semiquantitative analysis of Ki67, Bcl-2 and Bax protein expression in the rat mammary tumor cells after simvastatin treatment and the expression of Ki67, Bcl-2 and Bax in the control carcinoma cells of low or high grade, respectively.

\begin{tabular}{ccccc}
\hline Antibody against to & Control group & Simvastatin group & Control low grade cells & Control high grade cells \\
\hline Ki67 & $17.70 \pm 1.80$ & $12.93 \pm 3.01(-27 \%)$ & $15.17 \pm 2.40$ & $20.73 \pm 2.58[+37 \%]$ \\
Bcl-2 & $94.41 \pm 1.47$ & $82.82 \pm 6.06(-12 \%)^{\mathrm{a}}$ & $92.63 \pm 2.00$ & $96.67 \pm 2.11[+4 \%]$ \\
Bax & $77.06 \pm 3.57$ & $67.14 \pm 11.69(-13 \%)$ & $73.16 \pm 5.25$ & $82.00 \pm 4.49[+12 \%]$ \\
\hline
\end{tabular}

Data are expressed as means \pm SEM. Values in brackets are calculated as \%-ual deviation from the $100 \%$ of non-

influenced control group (round brackets) or low grade cells (square brackets).

Significantly different, ${ }^{\mathrm{a}} \mathrm{P}<0.05$ vs CONT. 
a) Ki67 detection has shown higher proliferation activity in the cells of control group compared to simvastatin group (magnification 400x).

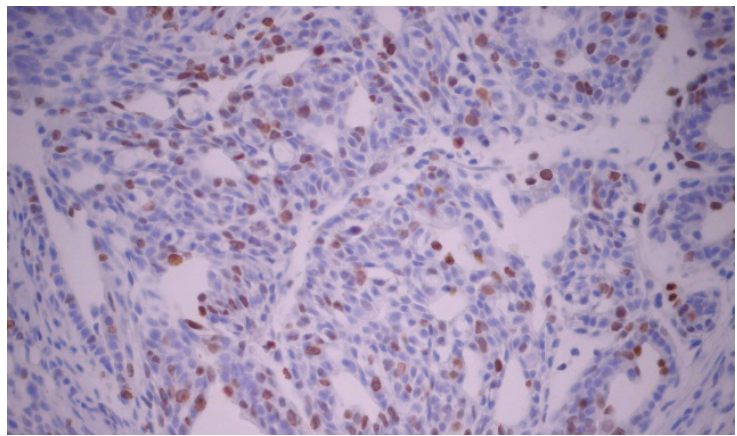

control group

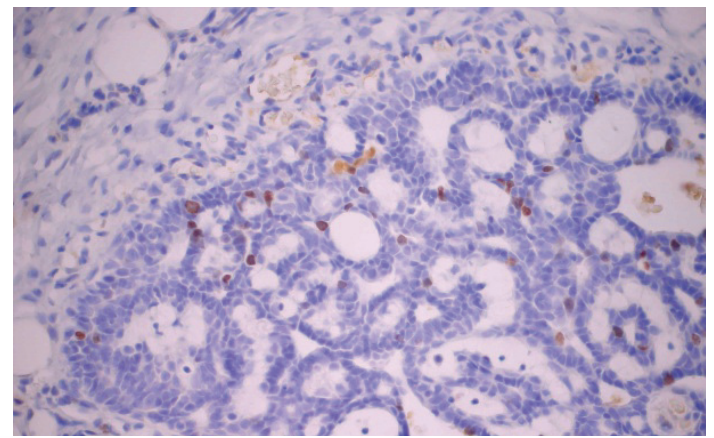

simvastatin group

b) Bcl-2 detection has shown significantly higher expression in tumor cells of control group (400x).

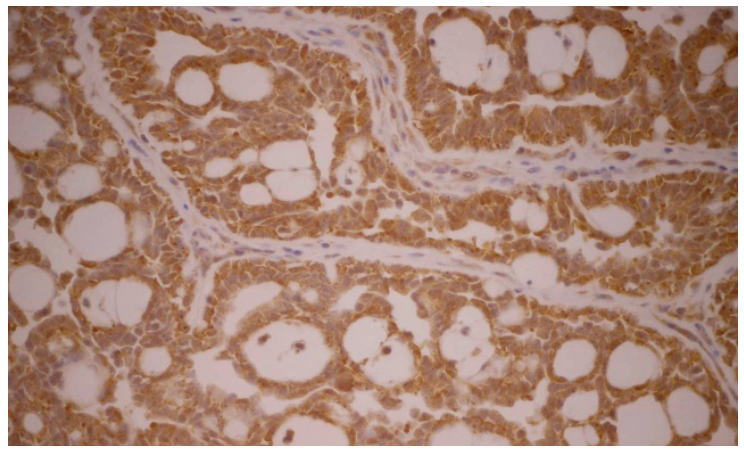

control group

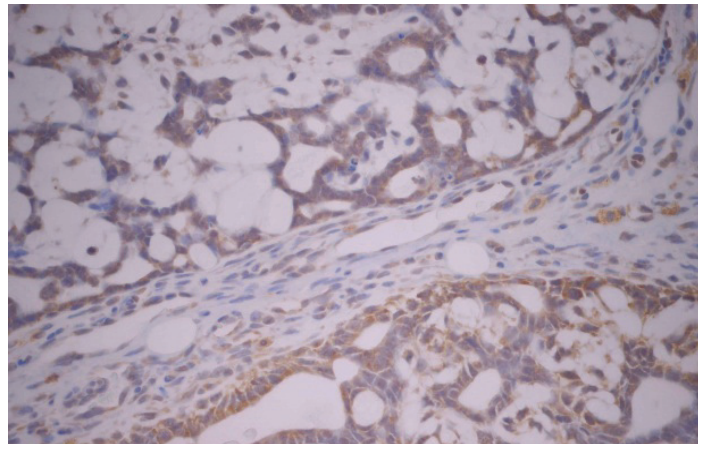

simvastatin group

c) Bax protein expression in tumor cells from control group and tumor cells treated by simvastatin (400x).

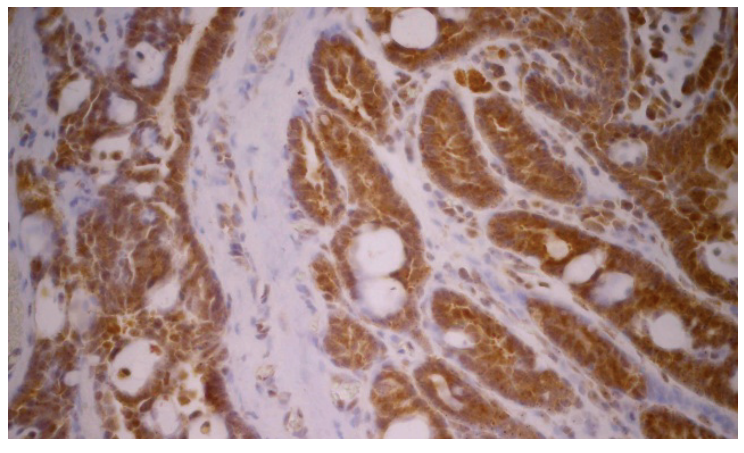

control group

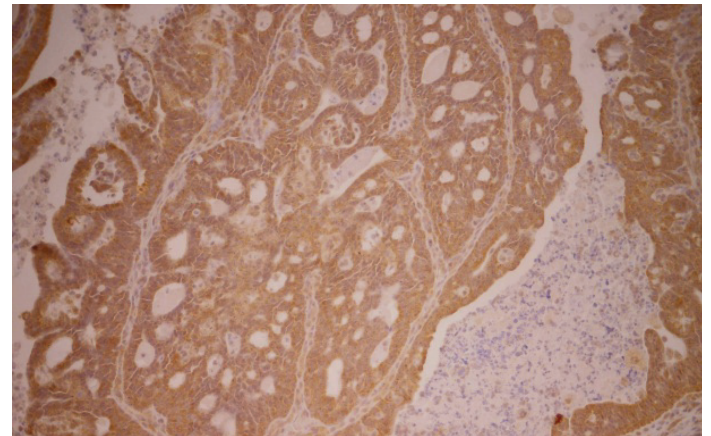

simvastatin group

Figure 1. The immunohistochemical detection of Ki67, Bcl-2 and Bax protein expression in mammary tumor cells after treatment with simvastatin $(180 \mathrm{mg} / \mathrm{kg})$.

expression of Bcl-2 and Bax did not significantly differ between control LG and control HG invasive tumor cell groups. In addition to the above mentioned statistical analysis, in the tumor cells from treated group (compared to control tumor cells), more frequent occurrence of some histomorphological signs of apoptosis were observed - shrinking of the cells, fragmentation of the nucleus, dense cytoplasm, karyorhexis, apoptotic bodies.

\section{Discussion}

This experiment is the first report about simvastatin used in mammary carcinogenesis in female rats. A significant chemopreventive effect of simvastatin administered in the concentration of $180 \mathrm{mg} / \mathrm{kg}$ of the diet was recorded in all parameters of mammary carcinogenesis. In addition, simvastatin in this experimental group was also effective in the 

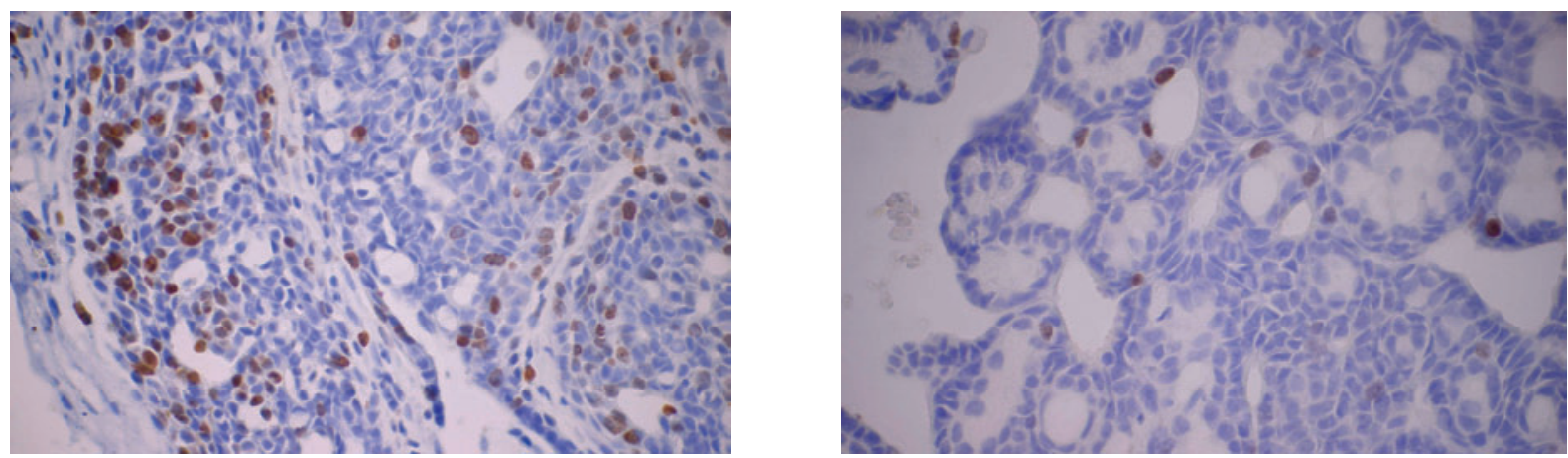

Figure 2. The nuclear positivity of Ki67 protein in high grade (on the left) and low grade (on the right) control carcinoma cells (magnification 600x).

treatment of tumors - the drug distinctly reduced the number of malignant lesions in favour of benign tumors. Moreover, a histopathological analysis of mammary tumors has revealed a shift from poorly to well differentiated invasive tumors after simvastatin administration $(180 \mathrm{mg} / \mathrm{kg})$. On the other hand, the lower concentration of simvastatin $-18 \mathrm{mg} / \mathrm{kg}$ in our experiment (equivalent to daily clinical doses) was ineffective in animals. Similarly, significant antitumor effects of atorvastatin $(100 \mathrm{mg} / \mathrm{kg}$ of diet $)$ administered in the chemoprevention of NMU-induced rat mammary carcinogenesis in our previous study were observed [9]. In our last experiment, hydrophilic rosuvastatin $(250 \mathrm{mg} / \mathrm{kg}$ of diet) has shown lower chemopreventive activity than lipophilic statins in this model of experimental breast cancer [13]. Narisawa et al. [14] in 1,2dimethylhydrazine-induced colon carcinogenesis in ICR mice, used as a chemopreventive agent dietary administered simvastatin at concentrations of $0.01 \%(100 \mathrm{mg} / \mathrm{kg})$ and $0.002 \%$ $(20 \mathrm{mg} / \mathrm{kg})$ and pravastatin administered in drinking water at concentrations of $0.01 \%, 0.001 \%$ and $0.005 \%$. Both agents significantly reduced tumor frequency. Anticarcinogenic effects of statins were proved also in other in vivo experiments. Pravastatin administered in drinking water has been shown to reduce the incidence and volume of $\mathrm{N}$-nitrosomorpholineinduced hepatic neoplastic nodules in Sprague-Dawley rats [15] and to reduce N-methyl-N-nitrosourea induced F344 rat colon carcinogenesis [16].

Recent in vitro studies have proven direct or indirect effects of statins on regulation mechanisms of the cell e.g. proliferation or apoptosis. Antiproliferative effects of statins include the inhibition of dolichol, geranylpyrophosphate and farnesylpyrophosphate, the stabilization of the cell cycle kinase inhibitors p 21 and p 27 and inhibition of Ras- and Rhomediated cell proliferation $[2,3]$. Emerging data indicate that statins demonstrate antiproliferative effects in several types of proliferating tumor cells. In vitro studies on various cell lines have shown that statins stimulated inhibitory potential, either by induction of G1-arrest or G2/M-arrest [17,18]. Zhang et al. [8] have observed that fluvastatin inhibited proliferation of hepatocellular carcinoma cell lines (HepG2, SMMC-7721 and
Table 4. Morphometrical analysis of Bcl-2 and Bax protein expression in mammary tumor cells after treatment with simvastatin.

\begin{tabular}{lccc}
\hline Group & $\begin{array}{c}\text { Percentage of } \\
\text { all labelled cells }\end{array}$ & \multicolumn{2}{c}{$\begin{array}{c}\text { Percentage of cells with weak and } \\
\text { mild/strong immunoreactivity }\end{array}$} \\
\cline { 3 - 4 } & & \multicolumn{3}{c}{+} & +++++ \\
\hline Bcl-2 protein & & & \\
\hline Control group & $7.39 \pm 0.66$ & $6.13 \pm 0.61$ & $1.26 \pm 0.55$ \\
Simvastatin group & $3.42 \pm 1.29^{*}$ & $3.23 \pm 1.27^{*}$ & $0.19 \pm 0.05$ \\
\hline Bax protein & & & \\
\hline Control group & $1.85 \pm 0.29$ & $1.33 \pm 0.22$ & $0.51 \pm 0.22$ \\
Simvastatin group & $3.08 \pm 0.84$ & $2.25 \pm 0.56$ & $0.82 \pm 0.34$ \\
\hline
\end{tabular}

Data are expressed as means \pm SEM. Intensity of immunoreactivity: weak $(+)$, mild $(++)$, strong $(+++)$.

Significantly different, ${ }^{*} \mathrm{P}<0.05$ vs CONT.

MHCC-97H) by inducing apoptosis and G2/M phase arrest in a dose-dependent manner. In another experiment, acquired data demonstrated that lovastatin inhibits the proliferation of MART-1-specific human cytolytic T lymphocytes without affecting cytolytic capacity [19]. In the study of Bessler et al. [20] malignant cell lines - HuCC, EHEB, K562, and Raji were incubated with three lipophilic statins (atorvastatin, lovastatin, and simvastatin) and one hydrophilic statin (pravastatin). All used statins inhibited HuCC cell proliferation. EHEB and K562 cell proliferation was inhibited by the lipophilic statins, but not by pravastatin. Raji cell proliferation was not affected by any of the used statins. The results of this experiment pointed out that the antiproliferative effect of statins on tumor cells depends on their dosage, physiochemical property, and the type of the malignant cells. Additionally, cerivastatin induced G1-arrest in breast cancer cells, but signs of apoptosis were not observed [3]. These results suggest that statin-induced effects on proliferation and apoptosis are independent. Ki67 is a cancer antigen that is found in growing, dividing cells but is absent in the resting phase of cell growth. This characteristic makes Ki67 a good tumor marker, e.g. meta-analysis of De Azambuja et al. [21] suggested that Ki67/MIB-1 positivity confers a higher risk of relapse and a worse survival in patients 
with early breast cancer. The effect of statin on Ki67 expression in tumor cells was evaluated in a recent experimental study [22]. The nude mouse xenograft assay showed that combination of epigallocatechin-3-gallate and lovastatin suppressed esophageal cancer cell growth and reduced the expression of Ki67. In our study, the expression of Ki67 protein in mammary tumor cells was also evaluated. The decrease of Ki67 protein expression by $27 \%$ observed in simvastatin treated cells compared to control cells points out to milder antiproliferative effects of the drug by above mentioned mechanisms of action. Additional immunohistochemical analysis of Ki67 confirmed higher protein expression in control high grade invasive tumor cells (by 37\%) compared to control low grade group - this result indicate that Ki67 as a reliable marker of proliferation may have a reasonable prognostic and predictive value in invasive breast cancer cells.

It is known that statins differs in their proapoptotic effects in variety of cancers. Lipophilic statins have been shown to induce apoptosis in various cell types, including vascular smooth muscle cells [23] cardiac myocytes [24], hepatocytes [25] and glioma cells [26], whereas hydrophilic statins (rosuvastatin and pravastatin) have not [27]. In the recent study of Kato et al. [28], the apoptotic potential of two lipophilic statins - lovastatin and simvastatin and one hydrophilic statin - pravastatin was assessed in ovarian, endometrial and cervical cancer cell lines. Lovastatin and simvastatin, but not pravastatin induced cell death through activation of extrinsic and intrinsic apoptotic cascades (caspase-8 and -9; BID cleavage, cytochrome $\mathrm{C}$ release and PARP cleavage) in cancerous cells, which expressed high levels of HMG-CoA reductase. In our study, after highly effective treatment of rat mammary tumors by simvastatin, we have evaluated the possible role of $\mathrm{Bcl}-2$ and Bax proteins in the drug's mechanism of action. Using semiquantitative and morphometrical methods, simvastatin has indicated proapoptotic shift in $\mathrm{Bax} / \mathrm{Bcl}-2$ ratio. The drug significantly decreased antiapoptotic $\mathrm{Bcl}-2$ protein expression in treated tumor cells compared to tumor cells in control animals. Non-significant, but evident increase of proapoptotic Bax protein expression in the group of treated tumor cells was observed after morphometrical analysis (despite the fact that semiquantitative analysis has shown non-significant decrease of Bax expression in treated cells). The results of this study indicate an important role of Bcl-2 apoptosis-regulatory protein and probably not relevant role for Bax protein in the pathogenesis of rat mammary tumors treated by simvastatin. Some experimental evidence suggests that in breast cancer, development, progression and an increased proliferation rate can be linked to apoptosis-related factors. Similarly than in our study, Sirvent et al. [29] studied 186 cases of infiltrating ductal breast carcinoma and concluded that Bax expression did not provide a new prognostic role, although it contrasted to the $\mathrm{Bcl}-2$ action. Another study summarized that a high $\mathrm{Bcl}-2$ expression had prognostic value in breast cancer patients treated with neoadjuvant anthracycline based chemotherapy [30].
The results of this study clearly pointed to simvastatin 's antineoplastic effects in experimental rat mammary carcinogenesis. Our study is the first report about Ki67, Bcl-2 and Bax protein immunohistochemical analysis in mammary tumor cells in vivo after treatment with statin. Our results pointed out to proapoptotic and antiproliferative effects of simvastatin in rat mammary carcinogenesis. Histomorphological analysis of tumors has shown apparent shift from malignant to benign lesions and shift from high grade to low grade carcinomas after simvastatin administration; in terms of clinical use this is an interesting result because long-term applied simvastatin may improve the disease prognosis and thus lifespan in oncological patients. Anticipated proapoptotic and antiproliferative effects or antiangiogenetic and antimetastatic mechanism of action of statins along with the favourable results from clinical oncological research have provided a rationale for future use of statins as potential anticancer reagents in the growth control of breast cancer.

Acknowledgements: The experiment was approved by Ethical Commission of Jessenius Faculty of Medicine of Comenius University (Protocol No. EK 320/2007) and by State Veterinary and Food Administration of the Slovak Republic (accreditation No. Ro-2061/08-221). This work was supported by the Scientific Grant Agency of the Ministry of Education of the Slovak Republic under contract no. VEGA 1/0029/08.

\section{References}

[1] HINDLER K, CLEELAND CHS, RIVERA E, COLLARD CHD The role of statins in cancer therapy. Oncologist 2006; 11: 306-315. http://dx.doi.org/10.1634/theoncologist.11-3$\underline{306}$

[2] RAO S, LOWE M, HERLICZEK TW, HERLICZEK T, LOWE M, KEYOMARSI K Lovastatin mediated G1 arrest in normal and tumor breast cells is through inhibition of DK2 activity and redistribution of p21 and p27, independent of p53. Oncogene 1998; 17: 2393-2302. http://dx.doi.org/10.1038/ sj.onc. 1202322

[3] DENOYELLE C, VASSE M, KORNER M, MISHAL Z, GANNE $F$ et al. Cerivastatin, an inhibitor of HMGCoA reductase, inhibits the signaling pathways involved in the invasiveness and metastatic properties of highly invasive breast cancer cell lines: an in vitro study. Carcinogenesis 2001; 22: 1139-1148. http://dx.doi.org/10.1093/carcin/22.8.1139

[4] JIANG Z, ZHENG X, LYTLE RA, HIGASHIKUBO R, $\mathrm{RICH}$ KM Lovastatin-induced up-regulation of the $\mathrm{BH} 3$ only protein, Bim, and cell death in glioblastoma cells. J Neurochem 2004; 89: 168-178. http://dx.doi.org/10.1111/ j.1471-4159.2004.02319.x

[5] CAFFORIO P, DAMMACCO F, GERNONE A, SILVESTRIS F Statins activate the mitochondrial pathway of apoptosis in human lymphoblasts and myeloma cells. Carcinogenesis 2005; 26: 883-891. http://dx.doi.org/10.1093/carcin/bgi036

[6] AGARWAL B, BHENDWAL S, HALMOS B, MOSS SF RAMEY WG et al. Lovastatin Augments Apoptosis Induced 
by Chemotherapeutic Agents in Colon Cancer Cells. Clin Cancer Res 1999; 5: 2223-2229.

[7] OGUNWOBI OO, BEALES IL Statins inhibit proliferation and induce apoptosis in Barrett's esophageal adenocarcinoma cells. Am J Gastroenterol 2008; 103: 838-841.

[8] ZHANG W, WU JA, ZHOU L, XIE HY, ZHENG SS Fluvastatin, a lipophilic statin, induces apoptosis in human hepatocellular carcinoma cells through mitochondria-operated pathway. Indian J Exp Biol 2010; 48: 1167-1174.

[9] KUBATKA P, ZIHLAVNIKOVA K, SOLAR P, KAJO K, VALENTOVA $V$ et al. Antitumor effects of atorvastatin in the chemoprevention of rat mammary carcinogenesis. Biologia 2011; 66: 727-734. http://dx.doi.org/10.2478/s11756-011-0077-3

[10] SCHOLZEN T, GERDES J The Ki-67 protein: from the known and the unknown. J Cell Physiol 2000; 182: 311-322. http:// dx.doi.org/10.1002/(SICI) 1097-4652(200003)182:3<311:: AID-JCP1>3.0.CO;2-9

[11] RUSSO J, RUSSO IH Atlas and histologic classification of tumors of the rat mammary gland. J. Mammary Gland Biol. Neoplasia 2000; 5: 187-200. http://dx.doi.org/10.1023/ A:1026443305758

[12] KUBATKA P, ZIHLAVNIKOVA K, KAJO K, PEC M, STOLLAROVA $\mathrm{N}$ et al. Antineoplastic effects of simvastatin in experimental breast cancer. Klin Onkol 2011; 24: 41-45

[13] KUBATKA P, ZIHLAVNIKOVA K, KAJO K, STOLLAROVA $\mathrm{N}, \mathrm{PEC} \mathrm{M}$ et al. Rosuvastatin in the chemoprevention of $\mathrm{N}$ methyl-N-nitrosourea-induced mammary carcinogenesis in female rats. Acta Vet (Beograd) 2011; 61: 445-460. http:// dx.doi.org/10.2298/AVB1106445K

[14] NARISAWA T, FUKAURA Y, TERADA K, UMEZAWA A, TANIDA N et al. Prevention of 1,2-dimethylhydrazineinduced colon tumorigenesis by HMG-CoA reductase inhibitors, pravastatin and simvastatin, in ICR mice. Carcinogenesis 1994; 15: 2045-2048. http://dx.doi.org/10.1093/carcin/15.9.2045

[15] TATSUTA M, IISHI H, BABA M, ISEKI K, YANO H et al. Suppression by pravastatin, an inhibitor of $\mathrm{p} 21$ ras isoprenylation, of hepatocarcinogenesis induced by $\mathrm{N}$-nitrosomorpholine in Sprague-Dawley rats. Br J Cancer 1998; 77: 581-587. http:// dx.doi.org/10.1038/bjc.1998.94

[16] NARISAWA T, MOROTOMI M, FUKAURA Y, HASEBE $\mathrm{M}$, ITO $\mathrm{M}$ et al. Chemoprevention by pravastatin, a 3-hydroxy-3-methylglutaryl-coenzyme A reductase inhibitor, of $\mathrm{N}$-methyl-N-nitrosourea-induced colon carcinogenesis in F344 rats. Jpn J Cancer Res 1996; 87: 798-804. http://dx.doi. org/10.1111/j.1349-7006.1996.tb02103.x

[17] PARK C, LEE I, KANG WK Lovastatin-induced E2F-1 modulation and its effect on prostate cancer cell death. Carcinogenesis 2001; 22: 1727-1731. http://dx.doi.org/ $\underline{10.1093 / \mathrm{carcin} / 22.10 .1727}$

[18] VAN DE DONK NW, KAMPHUIS MM, LOKHORST HM, BLOEM AC The cholesterol lowering drug lovastatin induces cell death in myeloma plasma cells. Leukaemia (Baltimore) 2002; 16: 1362-1371.

[19] LI D, LI Y, HERNANDEZ JA, PATENIA R, KIM TK et al. Lovastatin inhibits $\mathrm{T}$-cell proliferation while preserving the cytolytic function of EBV, CMV, and MART-1-specific CTLs. J Immunother 2010; 33: 975-982. http://dx.doi.org/10.1097/ CJI.0b013e3181fb0486

[20] BESSLER H, SALMAN H, BERGMAN M, DJALDETTI M On the factors modulating the effect of statins on malignant cell proliferation. Cancer Invest 2007; 25: 279-284. http://dx.doi. org $/ 10.1080 / 07357900701208535$

[21] DE AZAMBUJA E, CARDOSO F, DE CASTRO JR G, COLOZZA M, MANO MS, et al. Ki-67 as prognostic marker in early breast cancer: a meta-analysis of published studies involving 12155 patients. Br J Cancer 2007; 96: 1504-1513. http://dx.doi.org/10.1038/sj.bjc.6603756

[22] YE F, ZHANG GH, GUAN BX, XU XC. Suppression of esophageal cancer cell growth usin curcumin, (-)-epigallocatechin-3-gallate and lovastatin. World J Gastroenterol 2012; 18: 126-135. http://dx.doi.org/10.3748/wjg.v18.i2.126

[23] GUIJARRO C, BLANCO-COLIO LM, ORTEGO M, ALONSO C, ORTIZ A et al. 3-Hydroxy-3-methylglutaryl coenzyme A reductase and isoprenylation inhibitors induce apoptosis of vascular smooth muscle cells in culture. Circ Res 1998; 83: 490-500.

[24] DEMYANETSS, KAUNC, PFAFFENBERGERS, HOHENSINNER PJ, REGA G et al. Hydroxymethylglutaryl-coenzyme A reductase inhibitors induce apoptosis in human cardiac myocytes in vitro. Biochem Pharmacol 2006; 71: 1324-1330. http://dx.doi.org/10.1016/j.bcp.2006.01.016

[25] KUBOTA T, FUJISAKI K, ITOH Y, YANO T, SENDO T, OISHI $\mathrm{R}$ Apoptotic injury in cultured human hepatocytes induced by HMG-CoA reductase inhibitors. Biochem Pharmacol 2004; 67: 2175-2186. http://dx.doi.org/10.1016/j.bcp.2004.02.037

[26] KOYUTURK M, ERSOZ M, ALTIOK N Simvastatin induces proliferation inhibition and apoptosis in C6 glioma cells via c-jun N-terminal kinase. Neurosci Lett 2004; 370: 212-217. http://dx.doi.org/10.1016/j.neulet.2004.08.020

[27] KATSIKI N, TZIOMALOS K, CHATZIZISIS Y, ELISAF M, HATZITOLIOS AI Effect of HMG-CoA reductase inhibitors on vascular cell apoptosis: Beneficial or detrimental? Atherosclerosis 2010; 211: 9-14. http://dx.doi.org/10.1016/ j.atherosclerosis.2009.12.028

[28] KATO S, SMALLEY S, SADARANGANI A, CHEN-LIN K, OLIVA B et al. Lipophilic but not hydrophilic statins selectively induce cell death in gynaecological cancers expressing high levels of HMGCoA reductase. J Cell Mol Med 2010; 14: 1180-1193.

[29] SIRVENT JJ, AGUILAR MC, OLONA M, PELEGRI A, BLAZQUEZ $S$ et al. Prognostic value of apoptosis in breast cancer (pT1-pT2). A TUNEL, p53, bcl-2, bag-1 and Bax immunohistochemical study. Histol Histopathol 2004; 19: 759-770.

[30] VARGAS-ROIG LM, CUELLO-CARRION FD, FERNANDEZ-ESCOBAR N, DAGUERRE P, LEUZZI $M$ et al. Prognostic value of $\mathrm{Bcl}-2$ in breast cancer patients treated with neoadjuvant anthracycline based chemotherapy. Mol Oncol 2008; 2: 102-111. http://dx.doi.org/10.1016/ j.molonc.2008.01.004 